\title{
Research on the Modern Inheritance of Chinese Dongyang Woodcarving Decoration Art*
}

\author{
Weiwei Shi \\ School of Art \& Design \\ Nanchang Hangkong University \\ Nanchang, China
}

\author{
Jun Song \\ School of Art \& Design \\ Nanchang Hangkong University \\ Nanchang, China
}

\begin{abstract}
Dongyang woodcarving is not only an art, but also a culture, expressing the propaganda of ceremonial culture and the symbol of the human spirit. In general, Zhejiang Dongyang woodcarving is self-contained in its carving content, composition and artistic style, showing its unique artistic charm as a national traditional art culture. However, the change of lifestyle and the lack of raw materials for production have forced the decoration art of Dongyang woodcarving to keep pace with the times, but it still inherits its traditional traditions, which are embodied in the inheritance of visual meaning and the inheritance of craftsmanship. In the end, in order to continue to promote the essence of this culture in the development of the inheritance, further discussion on how to further improve the inheritance mechanism.
\end{abstract}

Keywords-Dongyang woodcarving; decorative arts; heritage

\section{INTRODUCTION}

Zhejiang Dongyang woodcarving is one of the four famous Chinese carvings. It has been a history of more than a thousand years since Tang Dynasty. It is one of the most outstanding folk crafts of the Chinese nation and is known as the "National treasure". Because Dongyang woodcarving art is a folk craft of Dongyang, deep into people's daily lives, it is inevitably affected by people's psychology, emotions and concepts. Therefore, it reflects the local national culture personality and regional culture. Therefore, the cultural accumulation and connotation reflected by Dongyang Woodcarving is very profound.

\section{ANALYSis OF CULTURAL CONNOTATION AND ARTISTIC FEATURES OF DONGYANG WOODCARVING DECORATION}

\section{A. Analysis of the Cultural Connotation of Dongyang Woodcarving Decorative Art}

Not only decoration is an art or a culture, and gives it conveys a certain social cultural attributes. As a product of human civilization, decoration and human life are integrated into one, and dressing becomes a way of life, that is, an artistic way of life. Therefore, the value of Dongyang woodcarving art is not only that it is an important decoration in architecture, but also that it is also a complete art that can

*Note: Nanchang Hangkong University 2018 graduate innovation special fund project school-level project exist independently. Dongyang woodcarving decoration is an important part of the folk art in Zhejiang and part of the excellent traditional culture of the Chinese nation. It is an important carrier of the local natural environment, cultural life and economic development, values and folk customs, and fully reflects the local national culture and a spiritual trait that blends with traditional Chinese Confucianism, Taoism, and Buddhist culture. Analysis of the cultural connotation behind Dongyang woodcarving decorative patterns can promote us to build a general impression of Dongyang woodcarving art.

1) Propaganda of etiquette culture: The pursuit of "ceremonial" culture is an important cultural feature of Dongyang woodcarving decorative patterns. Whether it is animals, plants, auspicious patterns, etc., they all have a certain artistic conception, they all have a certain ideological atmosphere, and some also have the ideology of Confucianism, Taoism and Buddhism. The woodcarving pattern will also involve the auspicious content of preaching the old and loving the young, respecting the parents, patriotic loyalty, or congratulating people on longevity, wealth, blessing, and peace. These express people's desire for a happy and happy life. The appearance of flowers, birds and insects in the pattern embodies people's optimistic and beautiful feelings about life; the auspicious and cherished beasts such as dragon and phoenix and unicorn express their auspicious and happy expectations, the patterns portrayed according to the classic historical stories set an example and promote the role of righteousness, reflecting people's pursuit of lofty ideals. These sculptural decorative patterns are not only decorative art, but more by combining the meanings and symbols to expressing people' $\mathrm{s}$ feelings about life' $\mathrm{s}$ emotions at the time.

2) In the embodiment of the human spirit: Dongyang woodcarving decorative art has rich connotations in many aspects. The "humanistic spirit" is the essence of it and is a valuable spiritual wealth of mankind. Its humanistic spirit is mainly reflected in these aspects; first, it reflects the spirit of self-improvement. Chinese culture has been concerned about real life since ancient times. Confucius said that "unknown life, knowing death," and said that "Tian Xingjian, gentleman to self-improvement." It is this 
philosophy of life that has nurtured the Chinese nation's courage to fight stubbornly against all unfairness, to create its own happy life by itself; second, the philosophical thinking of "Heaven and Man are one." From Confucius's "Benevolence Lovers" to Lao Zhuang's "Tao Law Nature", people emphasize the idea that people are in nature and return to nature. Under the influence of the concept of unity of nature and man, the ancient Chinese, when making the fax wood carving pattern, did not simply carry out the pure form design, but linking the scene to people and things, connecting with people's ideals, and establishing relationships with mountains and lakes is the so-called "people's spirit.". The idea of "Heaven and Man" has a wide influence on the design and application of Chinese traditional auspicious patterns.1 In Dongyang woodcarving, craftsmen often combine the things of nature with the good wishes of people. The content is also taken from nature, such as vegetation, flowers, birds, exotic animals, mountains and lakes, and the beautiful meaning is integrated into it.

\section{B. The Artistic Characteristics of Dongyang Woodcarving Decoration}

1) Carved content: "Engraving flowers for auspiciousness can be satisfactory; paintings must have a play, and a hundred looks can be tasteful" has become the basic norm and guiding principle of Dongyang woodcarving works. Dongyang wood carving decorative themes more for religious statues, historical allusions, folklore, auspicious animals, landscape gardening these five categories.The picture design is in the same vein as the traditional Chinese white painting. The pattern decoration is rich and varied. There are people, landscapes, flowers and birds, beasts, religious statues, etc. Among them, the characters are mostly taken from historical legends and myths. Mythological totems such as "White Snake Biography", "Mulan from the Army", etc., character stories are represented by "Liu Guan Zhang Sanjieyi", "Three British Wars Lu Bu", "Four Beauty" and so on. ${ }^{2}$ Traditional wood carving artists with ingenious composition in the form of carvings and diverse levels, the various types of theme, content-rich carvings vividly presented in front of the world.

2) Mode of composition: As a traditional modeling art, Dongyang wood carvings benefit to some extent from the traditional Chinese painting art. In terms of artistic techniques, Dongyang woodcarving handles the perspective relationship with high level, far and plane dispersal, and takes the scattered point perspective and bird's-eye perspective of traditional Chinese painting as the composition characteristics to fully display the content of

\footnotetext{
Hu Junhong. "The Embodiment of "Heaven and Man Unity" Thought in Chinese Furniture" J. Packaging Engineering, 2007, pp. 228230 .

Hua Dehan. “China Dongyang Woodcarving” M. Zhejiang Photography Press, 2001.
}

the picture. For example, the carving of the traditional building's shackles, ox legs, doors, windows and other parts often use the left and right symmetrical composition techniques, so that the space as a whole achieves balance, harmony, order and perfection, in line with the daily aesthetics of the people. At the same time, traditional dongyang wood carving also USES the essence of other arts, such as the traditional Chinese painting "white" composition, the use of scattered point perspective to deal with the picture far and near, virtual and level, to present the high and distant clear, full atmosphere and rich level of artistic characteristics, and finally achieve the flexible approach to show the effect of diverse composition.

3) Art style: The image in Dongyang woodcarving is vivid and vivid. The "carved body" adopts an exaggerated proportion, and the head and the short leg are short to emphasize the expression of the character. After that, the development of traditional painters to the realism of the characters further strengthened the characteristics of vivid and vivid. Dongyang woodcarving pays attention to fine carving and fine carving, and the composition is exquisite and rich in layers. Dongyang wood carving has the name of "white wood carving". It makes full use of the color of the material itself and the skill of craftsman and artisan.It is known as the "Civilian culture" which use a method that does not paint, or only light colors.

\section{THE MODERn DEVELOPMENT OF DONGYANG WOODCARVING}

The French enlightenment philosopher Rousseau once said that "craft is the oldest and most honest labor of mankind. It plays the most important role in human development. It harmonizes body and mind through touch, vision and human brain, enabling people to grow healthily.". The decorative art of Dongyang woodcarving is not only a traditional handicraft, but also a part of the traditional visual culture of Zhejiang local people. It has gradually developed and developed in the course of a long history. Visual symbols are an artistic form of the inheritance and expression of national culture. It completes the display and inheritance of culture through its unique artistic features and rich art forms. Therefore, Dongyang woodcarving decorative art is a part of Zhejiang traditional traditional visual culture and has a strong representativeness.

Dongyang woodcarving was originally used for the decoration of building components, but with the change of lifestyle and the reduction of precious wood, there are fewer and fewer wooden houses, which have affected the main purpose of Dongyang woodcarving art. In the early days, the tree species such as pine and eucalyptus, which are easy to obtain and rich in the area, were used as engraving materials. In the medium term, the wood carving works from the early Buddhist supplies to the development of architecture and furniture. The materials were mainly eucalyptus, ginkgo and poplar. With the improvement of people's living standards, the improvement of living environment, the use of articles and the aesthetic appearance of articles, Dongyang 
woodcarvings also go to interior decoration, furniture, and woodcarving crafts mainly includes tables, chairs, coffee tables, screens, wardrobes, etc. At the same time, in terms of materials, it pays more attention to the rarity, preciousness and collectability of materials. Therefore currently, Phoebe, teak and Redwood and other high-grade wood are used.

\section{THE INHERITANCE OF DONGYANG WOODCARVING DECORATIVE ART}

\section{A. The Visual Meaning of Dongyang Woodcarving Decorative Art}

Dongyang woodcarving art has rich visual language, including flowers, vegetation, rare animals, mountains and rivers, and other elements. Its decorative language also contains rich meanings. In general, the visual communication characteristics of Dongyang woodcarving art is profound rich meanings, wood carving patterns often use a certain image and things to express the true feelings and profound implication. This is consistent with the characteristics of traditional Chinese art and is also a common expression of traditional Chinese poetry and painting.

The rich pattern of Dongyang woodcarving in decorative art expresses and conveys certain cultural information and social attributes. It exists as a carrier of folk thoughts, ideas and spirits. Each picture or combination of patterns of Dongyang woodcarving in the art of decoration contains auspicious and rich meanings. A variety of auspicious patterns are created in symbolic, homophonic, figurative and other methods.

Among the meanings, the most widely used theme is " $\mathrm{Fu}$ $\mathrm{Lu}$ Shou Xi". The usual visual expression technique is to engrave the words "shou" and "Fu" on the doors and windows of the building. At the same time, the use of the animal "bat" is equivalent to the blessing,the animal "sika deer" is equivalent to good fortune, the legendary beast is equivalent to life, thus symbolizing good fortune; at the same time, the four species of "turtle, deer, pine, and crane" also symbolize the meaning of longevity. They combine with each other to form "Helu Tongchun", "Songhe Changqing" etc., there are symbol of longevity; the traditional Chinese image of dragon and phoenix is a symbol of honor. The precious beast of Qilin, lion and tiger represent the noble, and the auspicious objects represented by hibiscus, peony, sea bream and sweet-scented osmanthus in plants are used in the wood carving pattern. The meaning of auspiciousness also contains an important meaning that is safe and peaceful. The meaning of peace and tranquility in the Dongyang woodcarving pattern is often expressed as the use of homophonic techniques, the treasure bottle as peace, and Ruyi and so on to express the wish of peace and wish.

The visual meaning of Dongyang woodcarving pattern is rich, and the content of performance is the true reflection of the vision of folk life. In the many decorative patterns of Dongyang woodcarving, most of them express the meaning of meanings such as benefiting and avoiding harm and praying for happiness.

\section{B. The Inheritance of the Decorative Art of Dongyang Woodcarving}

For people, tradition is accompanied by people's life. People first come into contact with traditional things from birth. Their living habits and life characteristics are influenced by tradition. For traditional culture, it is necessary to inherit and abandon it. This is because human society is moving forward, and culture is constantly developing and changing. It develops and innovates on the basis of existing culture. As the fundamental feature of culture, inheritance is the continuation and reproduction of culture. Inheriting national culture is a common phenomenon in human society to transmit and continue culture. As an excellent traditional craft culture of the Chinese nation, Dongyang woodcarving art is part of China's excellent traditional culture and contains the essence of traditional culture. Therefore, it is necessary for its inheritors.

At present, the inheritance of Dongyang woodcarving is mainly due to the inheritance of art and technology in the workshop. It is mainly carried out in the same way as "masters with apprentices". In the process of skill learning, the masters generally use the method of words and deeds to teach and teach skills while working. The apprentice helps while learning, by watching the actual operation of the master, keeping in mind the methods taught by the master to accumulate his skills. After waiting for a certain accumulation, the master will allow the apprentice to personally operate some of the steps that require higher processes. This unique style of respect and discipline, as well as strict training, not only promoted the woodcarving skills to be passed down from generation to generation, but also objectively promoted the spread of wood carving craftsmanship and techniques. However, the master often adopts an attitude of "Reserved single-handedly", When this step important, deliberately let the apprentice do other activities. This kind of conservativeness and closure sometimes causes certain technologies to be lost, which also makes Dongyang woodcarving have a certain negative impact in the mode of master and apprenticeship.

\section{CONCLUSION}

"The times have to move forward, and life needs to develop, not at the expense of abandoning a valuable culture." The targeted inheritance and dissemination of traditional culture is not only the protection of the traditional culture of the nation, but also a sustainable development strategy of the traditional culture of the nation in modern society. "Chuan" treats local culture as a splendid cultural heritage. It investigates, organizes, protects, and makes a large amount of information in its records. The fine works are preserved in the original and passed down. "Cheng" is the need of social metabolism. The purpose is to develop and spread culture and how to integrate the essence of traditional culture and traditional crafts with modern life with the development of the times and the change of lifestyle. As the British writer and Nobel laureate Eliot said, "The word tradition itself has the meaning of movement. It is a nonprohibited thing, something that is constantly being 
transmitted and absorbed." 3 The inheritance of research culture It not only helps us to understand the characteristics and laws of culture, but also has a positive practical significance for us to correctly handle the relationship between modernization and national traditional culture. In the ancient and excellent traditional decoration crafts of Dongyang woodcarving art, we should learn from and learn from the successful cases in the world. For inheritance and development, we should maintain two different routes at the same time.

The first is to establish Dongyang Woodcarving Museum, Handicraft Exhibition Hall or Dongyang Woodcarving Craft Ecological Village. The original appearance of Dongyang woodcarving craft is reproduced in the traditional original way. The traditional wood decoration and carving tools are used to display this excellent folk decoration craft. The "inheritance" is firstly to "pass" such original inheritance, protect the "essence" of Dongyang woodcarving art, protect the essence of the traditional taste and provide the foundation for further innovation in the future.

The second is to extract elements from the tradition and carry out innovative design. This second road is based on the first route, that is, to preserve the elements of the traditional wood carving process, extract elements and innovate. However, this kind of innovation is not a modern application of traditional patterns on the surface, nor is it so simple to put Dongyang wood carvings in modern bedrooms, but to apply modern materials and production techniques to design and produce new "Dongyang Wood Carvings". The Dongyang woodcarving is "contemporary", which makes the woodcarving craft and dialogue with modern daily life become a daily necessities.

How to maintain the vitality of our traditional non-legacy handicrafts and the diversity of their culture has become a major realistic issue. To this end, through the combing and analysis of the traditional Dongyang woodcarving art characteristics, value attributes and design ideas, so that more people can understand the thinking modes, behavioral norms and values contained in China's traditional handicraft culture, and feel the Dongyang woodcarving art and its The charm of culture, jointly explore the protection content and innovation path of Dongyang woodcarving art, so that it maintains a strong vitality and achieves the goal of sustainable development.

\section{REFERENCES}

[1] Xu Yiyi. " Problems and Thoughts of Traditional Arts and Crafts in the Present" J. Guizhou Social Sciences, 2014, pp. 29-33.

[2] Zheng Wei. "Dongyang Woodcarving Graphic Language and Creativity" M. Hangzhou: Zhejiang University Press, 2016.

[3] Hu Junhong. "The Embodiment of "Heaven and Man Unity" Thought in Chinese Furniture" J. Packaging Engineering, 2007, pp. 228-230.

[4] Hu Wei. "Reflections on the Development of Modern Process Design by Traditional Crafts" J. Journal of Packaging Engineering, 2009, pp. 129-131.

\footnotetext{
3 Xu Yiyi. "Problems and Thoughts of Traditional Arts and Crafts
} in the Present" J. Guizhou Social Sciences, 2014, pp. 29-33.
[5] Hua Dehan. "China Dongyang Woodcarving" M. Zhejiang Photography Press, 2001

[6] Wang Wei. "Research on Reproduction of Traditional Handicrafts" J. Xi'an Academy of Fine Arts, 2016. 